\title{
Species Composition and Abundance of Zooplankton in a Freshwater Ecotone in Akwa Ibom State, Southeastern Nigeria
}

\author{
Imaobong E. Ekpo ${ }^{1 *}$, Ofonmbuk I. Obot ${ }^{1}$, Godwin S. Adaka ${ }^{2}$, Mandu A. Essien-Ibok ${ }^{1}$, and Idongesit \\ I. Joseph ${ }^{3}$ \\ ${ }^{1}$ Department of Fisheries \& Aquatic Environmental Management, Faculty of Agriculture, University of Uyo, Uyo \\ ${ }^{2}$ Department of Fisheries and Aquaculture Technology, Federal University of Technology, \\ PMB 1526, Owerri, Imo State, Nigeria \\ ${ }^{3}$ Center for Wetlands and Waste Management Studies, Faculty of Agriculture, University of Uyo, Uyo
}

*Corresponding Author

Imaobong E. Ekpo

\section{Article History}

Received: 13.06 .2020

Accepted: 20.06.2020

Published: 13.07 .2020

\begin{abstract}
Investigation on species composition and abundance of zooplankton in Abak River, southeastern Nigeria was carried out for 12 months using filtration method. The result revealed that there were 5 taxonomic groups of zooplankton (namely: Cladocera, Copepoda, Nematoda, Polychaeta and Rotifera), comprising 81 cells/l, 13 species and 12 genera. The most abundant species was Polychaete larvae with 24 cells/l (29.63\%) whereas Alonella dadyi, Alona rectangula and Temora longicornis recorded the least (1 cell/l; 1.23\%). In terms of number of species, the most abundant zooplankton was the group Cladocera with 7 species $(53.86 \%)$ whereas the least were Nematoda and Polychaeta with only one species (7.69\%); represented in the following descending order: Cladocera > Rotifera and Copepoda > Polychaeta and Nematoda. However, in terms of number of cells per litre, Cladocera also had the highest number of cells (29 cells/1; 35.81\%) while the lowest number was observed in Copepoda with 3 cells/l $(3.70 \%)$; group contributions in descending order were as follow: Cladocera $>$ Polychaeta $>$ Rotifera $>$ Nematoda $>$ Copepoda. Low species composition and abundance of zooplankton observed in this study can be attributed to the anthropogenic perturbations on-going in and around the Abak River.
\end{abstract}

Keywords: species composition, abundance, zooplankton group, ecotone, cell count.

\section{INTRODUCTION}

Zooplankton (singular zooplankter) are weakly swimming microscopic animals that drift with water currents Dimowo [1] and are often referred to as "drifters" or "floaters" since they do not possess real powers to move against the water currents. They are the most important components of the aquatic ecosystem, playing a major role in energy transfer between the phytoplankton and the economically important fish populations Harris and Vanobaba [2]. Also, they play important role in the eutrophic structure of a river as consumers of the phytoplankton and act as a source of food for both shell and fin-fishes Ayodele and Adeniyi [3]; Ikhuoriah et al. [4]. Zooplankton, which are all those mixed group of tiny, living animals that float, drift freely or feebly swim in water column independent of the shore and bottom Sommer [5] and occupy the base level of food chains that lead up to commercially important fisheries have severally been used as bio-indicators of water quality Keller et al. [6]. They are recognized as pollution indicator organisms in the aquatic environment globally Rutherford et al. [7]; Yakubu et al. [8]; Abowei and Sikoki [9] and Ikhuoriah et al. [4].

Additionally, zooplankton is a biotic component of the aquatic ecosystems and plays a key role in cycling of organic materials, helping in regulating algal and microbial productivity through grazing, as suspension feeders and predators in the transfer of primary productivity to fish and other consumers Dejen et al. [10]. They serve as food for fish fry, fingerlings and other aquatic organisms and they play a major role in "Food web" of any aquatic ecosystem and could be induced or adversely affected by any of the environmental factors Kennie et al. [11]. They are ideal for theoretical and experimental population ecology due to their small sizes, short generation time and a relatively homogenous habit Ekpo [12].

Copyright @ 2020: This is an open-access article distributed under the terms of the Creative Commons Attribution license which permits unrestricted use, distribution, and reproduction in any medium for non commercial use (NonCommercial, or CC-BY-NC) provided the original author and source are credited. 
The villages around the Abak River are gradually transforming into urban settlements. The land use pattern around this area is also gradually changing from the mere peasant farming to a more sophisticated agricultural practice involving the use of fertilizers; other activities include riverbed dredging and untreated effluent discharges. Furthermore, establishment of various commercial and industrial centers could soon lead to contamination of these water resources in the near future. Currently, there is no published work on these important primary consumers in Abak River. Hence, the aim of this study is to bridge the gap in information on the zooplankton species composition and abundance, which will provide useful insights into the current water quality status of this aquatic ecosystem.

\section{Materials ANd Methods}

\section{Description of study Area}

The study was carried out across three communities in Abak Local Government Area (LGA), Akwa Ibom State, Nigeria, where the Abak River, a tributary of the Qua Iboe River flows through (Fig. 1). Thus, three Sampling Stations were established based on various human anthropogenic activities: Station 1 (Latitude: $5^{0} 01$ ' 09" 508N and Longitude: $7^{0} 48^{\prime} 53$ 00E) located in Ikot Obiofuk Ukpum community very close to the General Hospital and overhead bridge; Station 2 (Latitude: $4^{0} 59^{\prime} 27^{\prime \prime} 739 \mathrm{~N}$ and Longitude: $7^{0} 48^{\prime} 03^{\prime}$ "555E) located in Ikot Oku Mfang community very close the Late Archbishop Benson Idahosa Gospel Village and newly constructed flood drainage system which empties into this river and Station 3 (Latitude: $4^{0} 58^{\prime} 45^{\prime \prime} 355 \mathrm{~N}$ and Longitude: $7^{0} 47^{\prime} 48^{\prime}$ '957E) located in Ediene Abak community very close Tilapia Bar and Resort. It is important to note that the wastes generated by these structures are channeled into the Abak River without any pretreatment.

The mean annual rainfall received in this region is about $2500 \mathrm{~mm}$ with a mean annual temperature of about 32 ${ }^{0} \mathrm{C}$ and a relative humidity of $76 \%$. The topography, vegetation, water velocity and human activities in the study area vary across the sampling points. For instance, the topography of the river from the upstream has a valley structure where it forms a water fall as it flows in from its source down the ridges of the bridge. This has greatly influenced the speed of the water. The human activities observed included; bathing, laundry, minimal fishing and local sand mining using hand baskets. The river banks were mostly covered with grasses such as elephant grass (Pennisetum purpureum), screw pines (Pandamus spp.), shrubs, cover crops and scanty distribution of short-shady canopy tress. Parts of the riverbank was mostly used for peasant farming involving cultivation of fluted pumpkin (Telfairia occidentalis), waterleaf (Talinum triangulare), pepper (Capsicum annuum), cocoyam (Colocasia esculenta) and cassava (Manihot esculenta).

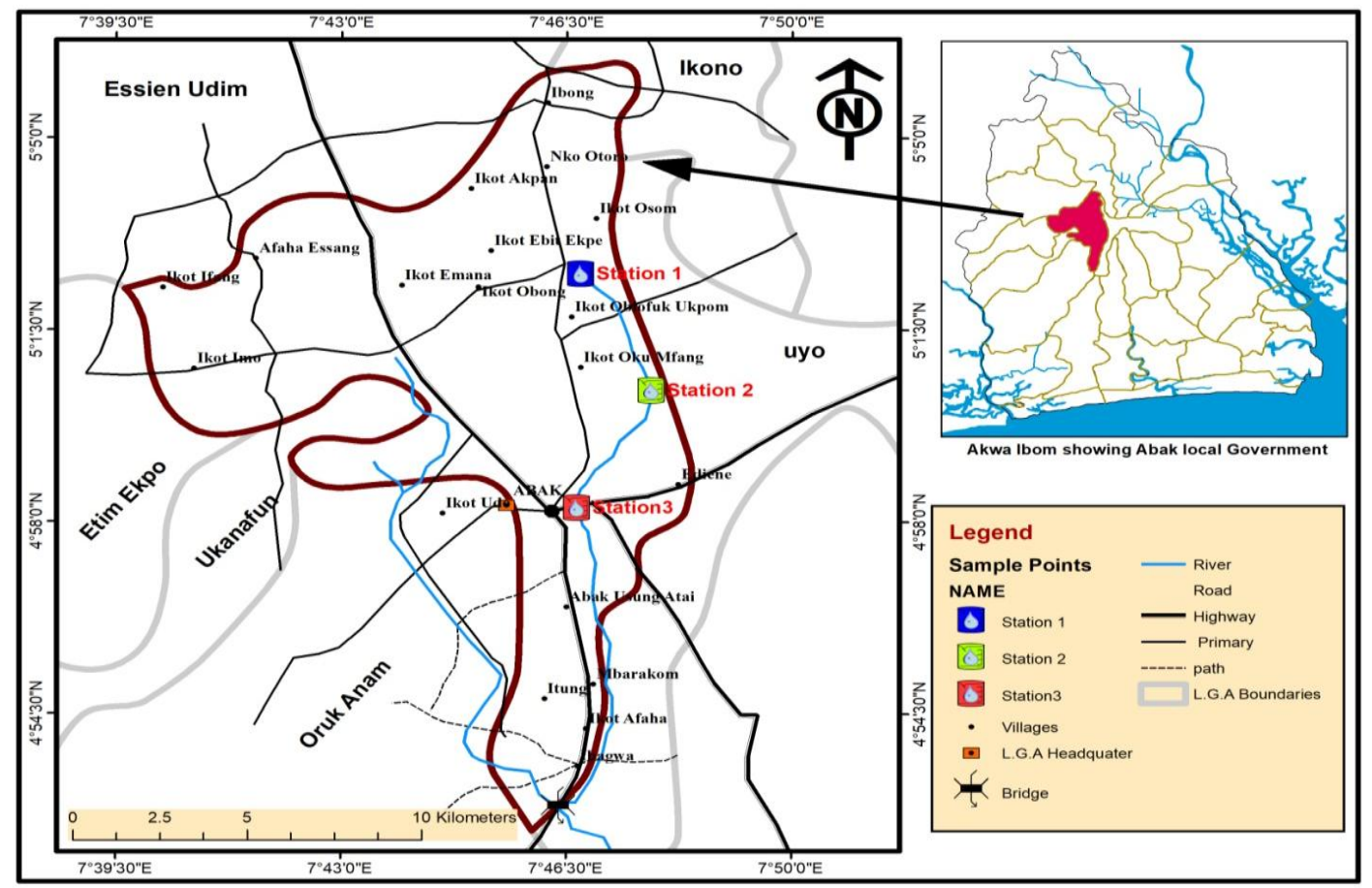

Fig-1: Map of Abak River showing the sampling stations (Insert: Map of Akwa Ibom State indicating the location of Abak LGA)

\section{Zooplankton collection and preservation}

Water samples for zooplankton analysis were collected quantitatively using plankton net with a standard mesh size of $55 \mu \mathrm{m}$. Zooplankton net was swept horizontally along each sampling stations for about 3 minutes just below the surface water. The samples were stored in one litre bottles and fixed with a solution of $10 \%$ formalin in the field immediately after collection to preserve the organisms from deterioration, and labelled appropriately according to 
sampling station and month. They were immediately transported to the Fisheries Laboratory in the Department of Fisheries \& Aquatic Environmental Management, Annex Campus, University of Uyo, Uyo, for analyses.

Preserved samples were allowed to settle to the bottom of the sample bottle, and then about three-quarter of the water sample was decanted into a beaker to concentrate the zooplankton specimens at the bottom of the bottle. The remaining one quarter of the decanted water sample was poured batch by batch into a petri dish just to cover the bottom of the petri dish. The petri dish with the subsample was mounted under the Leitz Wetzler binocular microscope using the scanning, low and high power objectives at 100-200x, 100-400x magnifications for viewing.

\section{Zooplankton identification and cell enumeration}

The composite species were identified with the aid of zooplankton identification guides, descriptions and illustrations such as Newell and Newell [13]; APHA-AWWA-WPCF [14]; Ricci and Melone [15]. Zooplankton identified were grouped into classes and species. The individual cells were counted and expressed as number of cells/litre.

\section{Statistical Analysis}

The statistical software package was employed for the analysis of the pooled generated data. These included descriptive statistics to determine the mean values, range values and analysis of variance (ANOVA).

\section{Relative abundance}

From the pooled raw data generated, individual species (n) of the zooplankton in each sample was enumerated to find the total number of all individuals $(\mathrm{N})$ in the family and used for the determination of the relative abundance (\%RA), using the formula:

$$
\begin{aligned}
& \% \mathrm{RA}=\mathrm{n} / \mathrm{N} \times 100 \\
& \text { Where, } \\
& \mathrm{RA}=\text { Relative abundance } \\
& \mathrm{n}=\text { Number of individual species in the sample } \\
& \mathrm{N}=\text { Total number of all the individual species in the family }
\end{aligned}
$$

\section{RESULTS}

\section{Zooplankton species composition and abundance}

The zooplankton species composition in Abak River revealed that there were thirteen species as depicted in Table 1. The most abundant species was Polychaete larvae with 24 cells/1 $(29.63 \%)$ whereas three species (Alonella dadyi, Alona rectangula and Temora longicornis) recorded the lowest (1 cell/1; 1.23\%). The two species of Rotifera (Lacane lunula and Philodina sp) had 8 cells/1 (9.87\%) each. Of the 7 species of cladocerans identified, the most abundant species was Nauplii larvae having 12 cells/l (14.81\%) while the lowest was Alonella dadyi and A. rectangula with 1 cell/1 (1.23\%). Other cladocerans were Moina sp (2 cells/1; 2.47\%), Ceriodaphnia sp (3 cells/1; 3.70\%), A. diaphnia and Bosmina coregoni (5 cells/1; 6.17\%). Copepoda had only two species: Canthocalanus sp and Temora

\begin{tabular}{|c|c|c|c|}
\hline Zooplankton class/Species & No. of species & No. of cells/l & $\%$ abundance \\
\hline Rotifera & 2 & & \\
\hline Lacane lunula & & 8 & 9.87 \\
\hline Philodina sp. & & 8 & 9.87 \\
\hline Sub-total & $2(15.38)$ & 16 & 19.75 \\
\hline Cladocera & 7 & & \\
\hline Alonella dadyi & & 1 & 1.23 \\
\hline Alona diaphnia & & 5 & 6.17 \\
\hline A. rectangula & & 1 & 1.23 \\
\hline Bosmina coregoni & & 5 & 6.17 \\
\hline Ceriodaphnia sp. & & 3 & 3.70 \\
\hline Moina sp. & & 2 & 2.47 \\
\hline Nauplii larvae & & 12 & 14.81 \\
\hline Sub-total & $7(53.86)$ & 29 & 35.81 \\
\hline
\end{tabular}
longicornis, whose recorded abundance were 2 cells/l $(2.47 \%)$ and 1 cell/1 $(1.23 \%)$ respectively. Polychaeta and Nematoda classes recorded only one specie each: Polychaete larvae (24 cells/1; 29.63\%) and Angiostrongylus sp (9 cells/l; $11.11 \%$ ) respectively.

Table-1: Zooplankton group/species composition in Abak River, Nigeria 


\begin{tabular}{|l|l|l|l|}
\hline Copepoda & 2 & & \\
\hline Canthocalanus sp. & & 2 & 2.47 \\
\hline Temora longicornis & & 1 & 1.23 \\
\hline Sub total & $\mathbf{2 ( 1 5 . 3 8 )}$ & $\mathbf{3}$ & $\mathbf{3 . 7 0}$ \\
\hline Polychaeta & 1 & & \\
\hline Polychaete larvae Sub total & $\mathbf{1 ( 7 . 6 9 )}$ & $\mathbf{2 4}$ & $\mathbf{2 9 . 6 3}$ \\
\hline Nematoda & 1 & & \\
\hline Angiostrongylus sp. & & 9 & 11.11 \\
\hline Sub total & $\mathbf{1 ( 7 . 6 9 )}$ & $\mathbf{9}$ & $\mathbf{1 1 . 1 1}$ \\
\hline Grand Total & $\mathbf{1 3 ( 1 0 0 )}$ & $\mathbf{8 1}$ & $\mathbf{1 0 0}$ \\
\hline
\end{tabular}

\section{Zooplankton class abundance}

Table 1 and Fig. 2 showed that there were 5 classes of zooplankton, comprising 81 cells/l, 13 species and 12 genera. In terms of number of species, the most abundant zooplankton was the class Cladocera with 7 species $(53.86 \%)$ whereas the least were Nematoda and Polychaeta with only one species $(7.69 \%)$. The remaining two classes (Rotifera and Copepoda) recorded two species each, contributing 15.38\%. Summarily, the zooplankton class abundance in terms of number of species were in the following descending order: Cladocera > Rotifera and Copepoda > Polychaeta and Nematoda. Also, in terms of number of cells per litre, Cladocera made the highest number of cells $(29$ cells $/ 1 ; 35.81 \%)$ while the lowest number was observed in the class Copepoda with 3 cells/l $(3.70 \%)$. The second highest number of cells were obtained in Polychaeta (24 cells/l; 29.63\%). Others were the class Rotifera which had 16 cells/1 (19.75\%) and the class Nematoda with 9 cells/l (11.11\%). In summing up the number of cells/l, the class contribution in a descending order were as follow: Cladocera $>$ Polychaeta $>$ Rotifera $>$ Nematoda $>$ Copepoda.

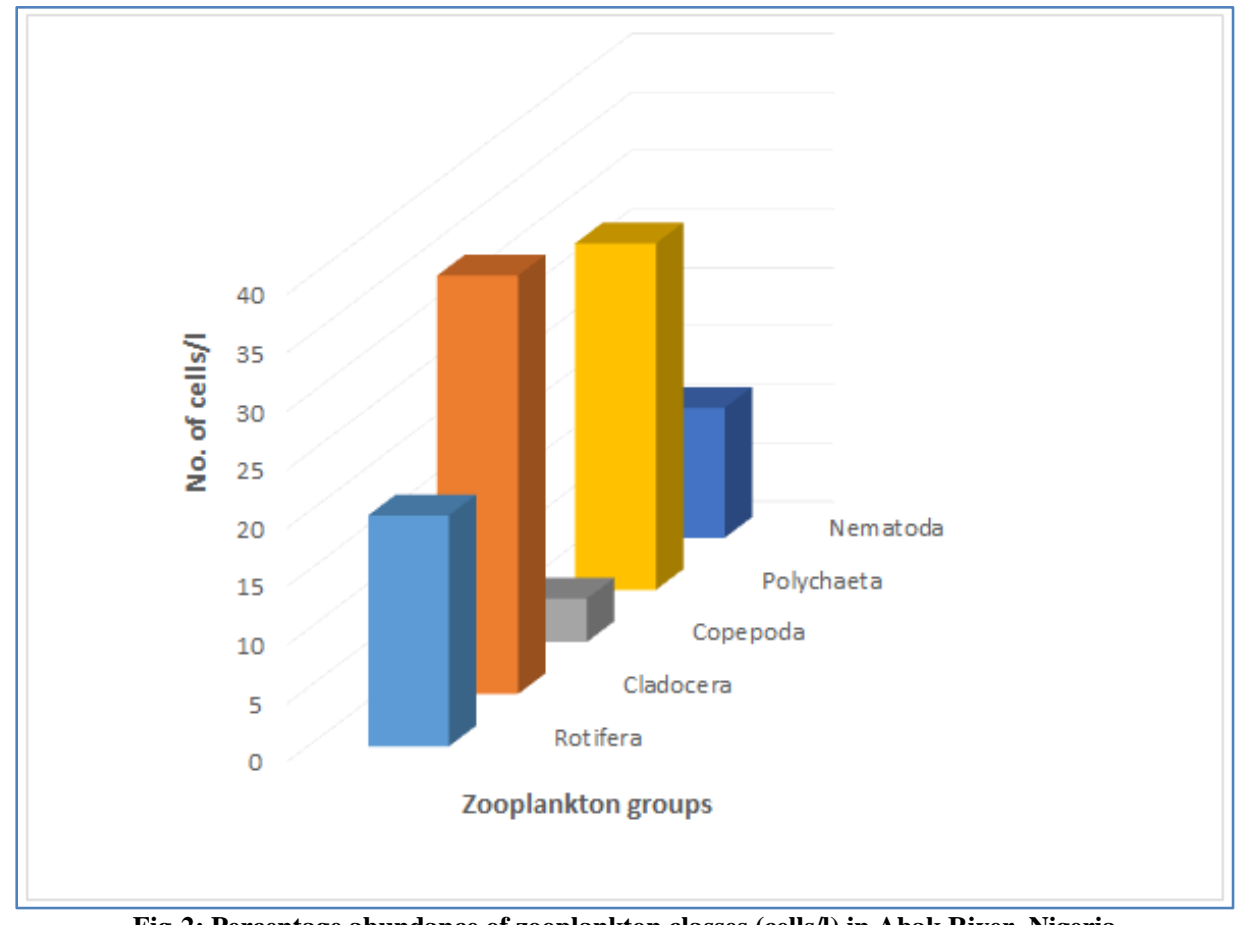

Fig-2: Percentage abundance of zooplankton classes (cells/l) in Abak River, Nigeria

\section{Recorded zooplankton abundance in some selected Nigerian systems}

Variations in the abundance of zooplankton in the Nigerian fluvial ecosystems have been well reported as seen in Table 2. Different water bodies, depending on some factors are endowed with different numbers and types of zooplankton. However, the most abundant taxon reported by many Nigeria authors was Copepoda with various percentage contributions. 
Table-2: A few recorded zooplankton abundances in some Nigerian lotic systems between 2010 and 2020

\begin{tabular}{|c|c|c|c|c|c|c|}
\hline \multirow{2}{*}{$\begin{array}{c}\text { Abundant } \\
\text { taxon }\end{array}$} & \multicolumn{7}{|c|}{ Number } & \multirow{2}{*}{ Reference* } \\
\cline { 2 - 6 } & Taxa & Species & Genera & Cells/indivs. & \% contribution & \\
\hline Copepoda & 7 & 15 & 13 & 309 & 48.50 & Ikomi \& Anyanwu, 2010 [16] \\
\hline Copepoda & 6 & 17 & 13 & - & 46.50 & Ezekiel et al., 2011 [17] \\
\hline Cladocera & 7 & 22 & 20 & 433 & 25.87 & Ogbuagu \& Ayoade, 2012 [18] \\
\hline Rotifera & 4 & 53 & 41 & 1,681 & 37.66 & Ekpo, 2013 [12] \\
\hline Copepoda & 3 & 42 & 22 & 1,330 & 51.10 & Ikhuoriah at al., 2015 [4] \\
\hline Crustacea & 8 & 45 & - & - & 48.00 & Essien-Ibok \& Ekpo, 2015 [19] \\
\hline otifera & 4 & 8 & 8 & 35 & 52.00 & Ekpo et al., 2015 [20] \\
\hline Protozoa & 4 & 79 & 61 & 61,000 & 51.00 & Wokoma, 2016 [21] \\
\hline Copepoda & 3 & 19 & - & 658 & 41.19 & Kennie et al., 2017 [11] \\
\hline Cladocera & 3 & 11 & 9 & 835 & 52.00 & Jonah \& George, 2019 [22] \\
\hline Rotifera & 5 & 20 & \multicolumn{7}{|c|}{} & 140 & 35.69 & Andem et al., 2019 [23] \\
\hline Maxillopoda & 6 & 9 & 9 & 440 & 50.00 & Obot et al., 2020 [24] \\
\hline
\end{tabular}

* References - Authors of the articles where the facts were extracted

\section{DiscUSSION}

Most tropical waters generally have low zooplankton species composition and diversity. Such observations have been reported in many tropical waters by many authors: Akin-Oriola [25], Ogbeibu et al. [26], Imoobe and Adeyinka [27] and in Table 1 above. These authors reported on typical tropical assemblages of zooplankton, noting that their structure had been used as indicator of nutrient and pollution statuses of their water bodies. The micro-communities in fresh water bodies constitute an extremely diverse assemblage of organisms represented by most of the invertebrate phyla, however, the dominant zooplankton includes rotifers, cladocerans, copepods and ostracods Kennie et al. [11]. Planktonic organisms tend to be more abundant in lentic systems such as lakes compared to lotic systems such as rivers, most likely as a result of water flow, Serafim-Jr et al. [28] revealed supporting the present results. Zooplankton communities' dynamics in the tropics has been attributed to a number of other factors such as the environmental characteristics of the water, predation, quality of edible algae and competition Hellawell [29]; Ovie and Adeniji [30]. The presence of a species will depend on its environmental tolerance but the resources available to it will determine its abundance Ikomi and Anyanwu, [16] and if competition or predation is reduced or the food supply or suitable habitat increased, the species will become more abundant Obot et al. [24]. Additionally, the observed high abundance recorded by Wokoma [21] might be linked with the duration of study and habitat (i.e. an estuary).

Thirteen species and five taxonomic groups of zooplankton were identified inthis work. This is similar to the findings of Dimowo [1] in Ogun River. However, this low species composition obtained is in disagreement with findings from many authors who reported a higher composition; among others include: Ezekiel et al. [17] opined a total of seventeen species belonging to six taxonomic groups in the Sombreiro River, Dimowo [1] reported a total of sixteen genera from five taxonomic groups recorded in Ogun River, Ekpo [12] reported 4 classes, 41 genera, 53 species and 1681 cells/l of zooplankton in Ikpa River, Ikhuoriah at al. [4] reported a total of 42 taxa, 11 species and 1330 individuals of cladocerans, 6 copepods and 5 rotifers in the following order of dominance: Copepoda > Cladocera > Rotifera in River Ossiomo, Obot et al. [24] revealed total of 9 species belonging to 6 taxonomic groups in Stubbs Creek, Kennie et al. [11] in which only three groups of zooplankton (Cladocera, Copepoda and Rotifera) were identified in the Jebba Upper Basin. However, as rightly observed by Imoobe and Adeyinka [27], the most dominant zooplankton species in West African freshwater ecosystems, viz., Keratella tropica, Keratella quadrata, Brachionus angularis, Trichocerca pusilla, Filinia longiseta, Pompholyx sulcata, and Proales sp., and others that are indicator species of high trophic levels, were not recorded in the river.

The most abundant species was polychaete larvae (Polychaeta). A dissimilar result was obtained by Ekpo [12], where Canthocamptus staphylinus (Copepoda) was the dominant species in station 1, Asplanchna priodonta (Rotifera) in station 2 and Bosmina longirosris (Cladocera) in station 3. The regularly most dominant species in West African lotic systems according to Imoobe and Adeyinka [31] were lacking in this study. In contrast to the observed trend in the present study, Uttah et al. [32] reported that polychaete larvae contributed $2.78 \%$ to the zooplankton abundance in Calabar River; making it second to the last taxon. It is worthy of note that these authors concluded that the river showed no evidence of stress beyond her carrying capacity, no evidence of any harmful environmental conditions and assessed it as being biologically suitable for contact in recreational activities. Larvae of planktonic annelids known as trocophores, are translucent, motile zooplankton, whose adults typically inhabit estuaries and subtidal zones, with some species 
inhabiting muddy intertidal zones, where they carry out the important function of sediment bioturbation in soft-bottoms, providing sediment stability and respiration Quale [33]. Polychaete worms sustain themselves from the available resources in their habitats and also directly make valuable contributions back to the ecosystem.

In terms of number of species and number of cells per litre, the most abundant zooplankton was the taxonomic group Cladocera. Similar results have been reported in Nigerian freshwater ecosystems: Ezekiel et al. [17] in Sombreiro River, Ude et al. [34] in Echara River, Ogbuagu and Ayoade [18] in Imo River, Dimowo [1] in Ogun River. However, the finding in this present work is at variance with the observation of Kennie et al. [11] in the Jebba Upper Basin in which the dominant taxonomic group was Cladocera. Also, Ekpo [12] observed that the dominant class was Rotifera in Ikpa River. Ikhuoriah et al. [4] showed that the dominant copepod and cladoceran species were Thermocyclops neglectus and Alona eximia representing $33.1 \%$ and $15.8 \%$ of the total zooplankton, respectively. The observed differences may be attributable to the differences in the habitats, sampling methods, duration of study, climatic and ecological variables. Moreover, this finding agrees with Ezekiel et al. [17] that the low zooplankton abundance and diversity observed must have been caused by the polluted nature of the water due to the anthropogenic activities carried out around its shores.

The Copepoda recorded the least in abundance in this study. This finding is not in consonant with other studies where they are found to be dominant taxon Egborge [35]; Jeje and Fernando [36]; Ikhuoriah et al. [4]. Copepods were the most abundant zooplankton taxon constituting more than half $(54.89 \%)$ of the zooplankton abundance in the Calabar River Uttah et al. [32]. Also, Barnes et al. [37] observed that copepods dominate most aquatic ecosystems because of their resilience and adaptability to changing environmental conditions and ability to withstand varying environmental stresses. Large cyclopoid species such as Canthocalanus sp., are voracious predators of first instar mosquito larvae. They can be more effective for biological control of mosquito breeding than other predatory invertebrates. Cyclopoids can only be numerically abundant in stagnant or slow water system. The low abundnace of this group of zooplankton in the present study is an indication that the Abak river is a fast moving water system.

Nematoda had only one species with 9 cells/l. Similar to this finding, Andem et al. [23] reported the least abundance of Nemata in a tropical river in southeastern Nigeria. Olomukoro and Ezemonye [38] revealed that the rare groups of macro-invertebrate fauna in southern Nigerian rivers were Nematoda (1.1\%), comprising of two species: Rhabdolaimus sp. and other nematode. The importance of nematodes as trophic intermediaries between microbial production and higher trophic levels such as other meiofauna, macro-invertebrates, and fishes have been reported by Majdi, and Traunspurger [39]. These authors further asserted a large intimate association of nematodes with bacteria and decaying detritus, with potential consequences on the decomposition process in lentic and lotic ecosystems.

The taxon, Rotifera with only two species was the third most abundant group and is known to be divided into three classes: Monogononta (with about 1500 species), Bdelloidea (with about 350 species), and Seisonidea (only 2 species). The rotifer, Brachonius calyciflorus (though not identified in this study) has been found to conserve energy when food is scarce by decreasing its respiration rate, while other species show no change in respiration rate Kelvin and Kirk [40]. The habitat of rotifers may include still water environments, such as lake bottoms, as well as flowing water environments, such as rivers or streams. Rotifers are also commonly found on mosses and lichens growing on tree trunks and rocks, in rain gutters and puddles, in soil or leaf litter, on mushrooms growing near dead trees, in tanks of sewage treatment plants, and even on freshwater crustaceans and aquatic insect larvae Örstan [41]; Kelvin and Kirk [40]. Macrophytes provide a fundamental element in the trophic chain by offering a variety of microhabitats used as refuges against visual predators and as reproductive sites for different taxa Duggan et al. [42] and Choi et al. [43] and distinct species of macrophytes can promote the development of specific rotifer assemblages associated with the architecture of the habitat and the spatial distribution of these plants (Velho et al. [44]; Lansac-Toha et al. [45]; Colares et al. [46]. Against these observations, Serafim-Jr et al. [28] opined that the hydrological phases, months and the environment type were important factors in the ecological structure of rotifers. However, common freshwater rotifers such as Keratella $s p$ reported by Egborge and Tawari [47]; Ekpo and Essien-Ibok [48] were not identified in the present study. The untreated waste waters from the General Hospital, recently constructed bridge, Gospel Centre, Tilapia Bar and Resort and the surrounding environment are the only pointers to that severe zooplankton species reduction in the study area. However, this result contrasted the study of Tawari-Fufeyin et al. [49] who recorded no specie of rotifer in River Ossiomo.

\section{CONCLUSION}

The most abundant species in terms of number of individuals was Polychaete larvae whereas three species (Alonella dadyi, Alona rectangula and Temora longicornis) recorded the lowest. Cladocera had the highest number of species, whereas the least were Nematoda and Polychaeta. The low status of zooplankton abundance and species composition i.e. five taxonomic groups, thirteen species, twelve genera, 81 cells/individuals; observed in this study must have been caused by the polluted nature of the water due to the anthropogenic activities carried out in and around it. There is, therefore, need to regulate the amount of pollutants discharged into the river so as to avoid total ecological collapse and extinction of the aquatic communities, thus adversely impacting the humans. 


\section{REFERENCES}

1. Dimowo, B. O. (2013). The zooplankton species composition and abundance in Ogun River, Abeokuta, Ogun State, Southwestern Nigeria. International Journal of Aquaculture, 3(3), 8-10.

2. Harris, J. M., \& Vinobaba, P. (2012). Impact of water quality on species composition and seasonal fluctuation of planktons of Batticaloa lagoon, Sri Lanka. J. Ecosyst. Ecogr., 2, 117.

3. Ayodele, H. A., \& Adeniyi, I. F. (2006). The zooplankton fauna of six impoundments on River Soun, southwest Nigeria. Tropical Freshwater Biology, 15, 121-128.

4. Ikhuoriah, S. O., Oronsaye, C. G., \& Adebanjo, I. A. (2015). Zooplankton communities of the River Ossiomo, Ologbo, Niger Delta, Nigeria. Animal Research International, 12(3), 2249-2259.

5. Sommer, U. (1994). Planktologie. Springer: 274.

6. Keller, B., Wolinska, J., Manka, M. \& Spaak, P. (2008). Philosophical transactions of the Royal Society B. Biological Sci., 363, 2943-2952.

7. Rutherford, S. D., Hondt, S., \& Prell, W. (1999). Environmental controls on the geographic distribution of zooplankton diversity. Nature, 400(6746), 749 - 753.

8. Yakubu, A. F., Sikoki, F. D., Abowei, J. F. N., \& Hart, S. A. (2000). A comparative study of phytoplankton communities of some creeks and borrow pits in the Niger Delta Area. Journal of Applied Science, Environment and Management, 4(2), $41-46$.

9. Abowei, J. F. N., \& Sikoki, F. D. (2005). Water pollution management and control. Double trust Publication Company, Calabar, Nigeria, 236.

10. Dejen, E., Vijverberg, J., Nagelkerke, L., \& Sibbing, F. (2004). Temporal and spatial distribution of microcrustacean zooplankton in relation to turbidity and other environmental factors in large tropical lake (L. Tana, Ethiopia). Hydrobiologia, 513, 39-49.

11. Kennie, A. M., Akinade, G. T., Ogialekhe, P., \& Mohammed, N. (2017). Zooplanktons assemblage along Jebba Upper Basin, Nigeria. International Journal of Pure and Applied Zoology, 5(3),

12. Ekpo, I. E. (2013). Effect of physico-chemical parameters on zooplankton species and density of a tropical rainforest river in Niger Delta, Nigeria using Canonical Cluster Analysis. The International Journal of Engineering and Science, 2(4), 13-21.

13. Newell, G. E., \& Newell, R. C. (1977). Marine plankton: A practical guide. Hutchinson and Company Publishers Ltd. London. 229pp.

14. American Public Health Association (APHA), American Water Work Association (AWWA) and Water Pollution Control Federation (APHA-AWWA-WPCF). (2005). Standard methods for the examination of water and wastewater. $21^{\text {st }}$ Edition, American Public Health Association Inc., New York. 1195.

15. Ricci, C., \& Melone, G. (2000). Key to the identification of the genera of bdelloid rotifers. Hydrobiologia, 418, $73-$ 80 .

16. Ikomi, R. B., \& Anyanwu, E. D. (2010). Zooplankton of Ogba River, Benin City, Nigeria. Biosci., Res. Commun, 22(5), 255-258.

17. Ezekiel, E. N., Ogamba, E. N. \& Abowei, J. F. N. (2011). The zooplankton species composition and abundance in Sombreiro River, Niger Delta, Nigeria. Asian Journal of Agricultural Sciences, 3(3), 200-204.

18. Ogbuagu, D. H., \& Ayoade, A. A. (2012). Spatial fluctuations in zooplankton biotypes of the Imo River in a Niger Delta area of Nigeria. International Journal of Ecosystem, 2(4), 54-60.

19. Essien-Ibok, M. A., \& Ekpo, I. E. (2015). Assessing the impact of precipitation on zooplankton community structure of a tropical river, Niger Delta, Nigeria. Merit Research Journal of Environmental Science and Toxicology, 3(2), 031-038.

20. Ekpo. I. E., Essien-Ibok, M. A., \& Duncan, A. O. (2015). Densities, spatial distribution and community structure of plankton of Odot Stream. Ecology and the Natural Environment, 7(6), 180-187.

21. Wokoma, O. A. F. (2016). Zooplankton species composition and abundance in the brackish water axis of Sombreiro River, Niger Delta. Applied Science Reports, 15(1), 31-36.

22. Jonah, U. E. \& George, U. U. (2019). Influence of water quality on zooplankton community structure of Etim Ekpo River, Akwa Ibom State, and South-South, Nigeria. World Rural Observ, 11(3); 49-57.

23. Andem, B., Odey, C. O., Imeh, E., \& Inyang, I. (2019). Ecological approach of plankton responses to water quality variables of a tropical river, South-Eastern Nigeria: A bio-indicator-based community assessment of Idundu River. Asian Journal of Fisheries and Aquatic Research, 3(1), 1-17.

24. Obot, O. I., David, G. S. \& Ekpo, I. E. (2020). Zooplankton assemblages of a tropical coastal creek, southeastern Nigeria. Ecologia, 10, 63-70.

25. Akin-Oriola, F. A. (2003). Zooplankton associations and environmental factors in Ogunpa and Ona Rivers, Nigeria. Rev. Biol. Trop, 51(2), 391-398.

26. Ogbeibu, A. E., Ezemonye, I. I. N., \& Uyigue, E. (2001). The crustacean zooplankton of the Ovie River, southern Nigeria. Nig. J. of Applied Sci., 19, 36-42.

27. Imoobe, T. O. T. \& Adeyinka, M. L. (2009). Zooplankton-based assessment of the trophic state of a tropical forest river in Nigeria. Archives of Biological Sciences, 61(4), 733-740. 
28. Serafim-Jr., M., Perbiche-Neves, G. \& Lansac-Toha, F. (2019). An assessment of the factors determining rotifer assemblage in river-lake systems: the effects of seasonality and habitat. Zoologia, 36, 1-8.

29. Hellawell, J. (1986). Biological indicators of freshwater pollution and environmental management. Elsevier, London.

30. Ovie, S. I., \& Adeniji. H. A. (1994). Zooplankton and environmental characteristics of Shiroro Lake at the extremes of its hydrological cycle. Hydrobiologia, 286, 175-182.

31. Imoobe, T. O. T. \& Adeyinka, M. L. (2010). Zooplankton-based assessment of the trophic state of a tropical forest river. International Journal of Fisheries \& Aquaculture, 2(2), 064-070.

32. Uttah, E. C., Uttah, C., Akpan, P. A., Ikpeme, E. M., Ogbeche, J., Usip, L. \& Asor, J. (2008). Bio-survey of Plankton as indicators of water quality for recreational activities in Calabar River, Nigeria. Journal of Applied Sciences and Environmental Management, 12(2), 35-42.

33. Quale, E. (2015). Evergreen: Visualizing microbial seascapes. Monograph project.

34. Ude, E. F., Ugwu, L. L. C., \& Mgbenka, B. O. (2011). Evaluation of zooplankton diversity in Echara River, Nigeria. Continental J. Biological Sciences, 4(1), 1-5.

35. Egborge, A. B. M. (1981). The composition, seasonal variation and distribution of zooplankton in Lake Asejire, Nigeria. Revue Zoologique Africaine, 95(1), 136.

36. Jeje, C. Y., \& Fernando, C. H. (1986). A practical guide to the identification of Nigerian zooplankton. Kainji Lake Research Institute Nigeria. Kainji Lake Res. Inst. 142pp.

37. Barnes, R. S. K., Calow, P., \& Olive, P. J. W. (1988). The invertebrates: a new synthesis. Blackwell Scientific Publications, London.

38. Olomukoro, J. O., \& Ezemonye, L. I. N. (2007). Assessment of the macro-invertebrate fauna of rivers in southern Nigeria. African Zoology, 42(1), 1-11.

39. Majdi, N., \& Traunspurger, W. (2015). Free-living nematodes in the freshwater food web: a review. Journal of Nematology, 47(1), 28-44.

40. Kelvin, L., \& Kirk, L. (1999). Physiological responses to variable environments: Storage and respiration in starving rotifers. Freshwater Biology, 42; 637-644.

41. Örstan, A. (1999). An introduction to Bdelloid rotifers. member.aol.com/bdelloid1/deloid.htm

42. Duggan, I. C., Green, J. D., Thompsom, K. \& Shiel, R. L. J. (2001). The influence of macrophytes on the spatial distribution of littoral rotifers. Freshwater Biology, 46, 777-786.

43. Choi, J. Y., Jeong, K. S., La, G. H., Chang, K. H., \& JOO, G. J. (2015) The influence of aquatic macrophytes on the distribution and feeding habits of two Asplanchna species (A. priodonta and A. herrickii) in shallow wetlands in South Korea. Journal of Limnology, 74(1), 1-11.

44. Velho, L. F. M., Lansac-Tôha, F. A., Takeda, A. M., Higuti, J. \& Franco, G. S. M. (2001). Structure and dynamics of the cyclopoid copepod (Crustacea) assemblage associated with aquatic macrophytes in two lotic environments of the Upper Paraná River basin, Brazil. Acta Scientiarum, 23(2), 349-356.

45. Lansac-Tôha F. A., Bonecker, C. C., \& Velho, L. F. M. (2004). Composition, species richness and abundance of the zooplankton community. In: Thomaz, S. M., Agostinho, A. A., Hahn, N. (Eds.) The Upper Paraná River and its floodplain: physical aspects, ecology and conservation. Leiden, Backhuys Publishers, 145-190.

46. Colares, M. A. M., Bonecker, C. C., Simões, N. R., Alves, G. M., \& Lansac-Tôha, F. A. (2013). Structure of zooplankton communities in macrophytes stands of a Neotropical floodplain (the Paraná River, Brazil). International Review of Hydrobiology, 98, 89-101.

47. Egborge, A. B. M., \& Tawari, P. (1987). The rotifers of Warri River, Nigeria. Journal of Plankton Research, 9(1), $1-13$.

48. Ekpo, I. E., \& Essien-Ibok, M. A. (2013). Studies on the biodiversity of zooplankton species in Ikpa River, Nigeria using Shannon-Wiener's biotic index. A paper presented at the $1^{\text {st }}$ International Conference on Oceanography held at University of Calabar, Calabar from $12^{\text {th }}-14^{\text {th }}$ November, 2013. Proceedings of the International Conference on Oceanography, $1 ; 251-260$.

49. Tawari-Fufeyin, P., Imoobe, T. O. T., \& Awana, B. B. (2008). The impact of bridge construction on the crustacean zooplankton of Ossiomo River, Niger Delta, Nigeria. African Scientist, 9; 117-122. 